\title{
Exercise program design considerations for head and neck cancer survivors
}

\author{
Adrian W. Midgley ${ }^{1}$ (D) Derek Lowe ${ }^{2} \cdot$ Andrew R. Levy $^{3} \cdot$ Vishal Mepani $^{4} \cdot$ \\ Simon N. Rogers ${ }^{2,5}$
}

Received: 16 August 2017 / Accepted: 26 September 2017 / Published online: 20 October 2017

(c) The Author(s) 2017. This article is an open access publication

\begin{abstract}
The present study aimed to establish exercise preferences, barriers, and perceived benefits among head and neck cancer survivors, as well as their level of interest in participating in an exercise program. Patients treated for primary squamous cell carcinoma of the head and neck between 2010 and 2014 were identified from the hospital database and sent a postal questionnaire pack to establish exercise preferences, barriers, perceived benefits, current physical activity levels, and quality of life. A postal reminder was sent to non-responders 4 weeks later. The survey comprised 1021 eligible patients of which 437 (43\%) responded [74\% male, median (interquartile range) age, 66 (60-73) years]. Of the respondents, 30\% said 'Yes' they would be
\end{abstract}

Adrian W. Midgley

adrian.midgley@edgehill.ac.uk

Derek Lowe

astraglobeltd@btconnect.com

Andrew R. Levy

andy.levy@edgehill.ac.uk

Vishal Mepani

v.mepani@hotmail.co.uk

Simon N. Rogers

snrogers.aintree@gmail.com

1 Department of Sport \& Physical Activity, Edge Hill University, Ormskirk L39 4QP, UK

2 Evidence-Based Practice Research Centre (EPRC), Edge Hill University, Ormskirk L39 4QP, UK

3 Department of Psychology, Edge Hill University, Ormskirk L39 4QP, UK

4 School of Medicine, University of Liverpool, Liverpool L69 3GE, UK

5 Consultant Regional Maxillofacial Unit, University Hospital Aintree, Liverpool L9 1AE, UK interested in participating in an exercise program and 34\% said 'Maybe'. The most common exercise preferences were a frequency of three times per week, moderate-intensity, and 15-29 min per bout. The most popular exercise types were walking (68\%), flexibility exercises (35\%), water activites/swimming (33\%), cycling (31\%), and weight machines (19\%). Home (55\%), outdoors (46\%) and health club/gym (33\%) were the most common preferred choices for where to regularly exercise. Percieved exercise benefits relating to improved physical attributes were commonly cited, whereas potential social and work-related benefits were less wellacknowledged. The most commonly cited exercise barriers were dry mouth or throat (40\%), fatigue (37\%), shortness of breath (30\%), muscle weakness (28\%) difficulty swallowing (25\%), and shoulder weakness and pain (24\%). The present findings inform the design of exercise programs for head and neck cancer survivors.

Keywords Exercise barriers - Exercise benefits - Exercise preferences · Oncology $\cdot$ Physical activity $\cdot$ Rehabilitation

\section{Introduction}

A mounting body of scientific evidence has shown that physical exercise improves aerobic fitness, strength, physical activity levels, and quality of life, and reduces fatigue in cancer survivors during and post treatment [1-3]. Decreased mortality also has been observed [4]. Accordingly, to promote safe and effective exercise, general cancer and cancer type-specific exercise prescription guidelines have been published [5-7]. An important issue is that sufficient research to support guidelines for less prevalent cancers do not exist and has resulted in the extrapolation of research findings from other cancers [6]. When considering certain cancers 
often differing in symptoms and treatment strategies, the need for more research to optimise exercise program design for survivors of less prevalent cancers is apparent.

Head and neck cancer represents a diverse set of tumours of the larynx, oropharynx, oral cavity, nasopharynx, nose, and paranasal sinuses [8], with an annual worldwide incidence of over 500,000 [9]. Symptoms consistent with other cancer types include pain, depression, fatigue, and intolerance to physical activity $[10,11]$. Other symptoms such as weight loss, head and neck oedema, dry mouth, mouth sores, dysphagia, and shoulder pain and dysfunction are specific to or more dominant in head and neck cancer [10, 12]. Another notable consideration is that individuals presenting with head and neck cancer historically are typically older, with prolonged exposure to smoking tobacco and high levels of alcohol consumption [13]. Comorbidities such as heart and lung disease are therefore typically more prevalent in head and neck cancer survivors [14]. There also has been an increase in younger and fitter individuals presenting with head and neck cancer due to a marked increased prevalence in the human papillomavirus [15]. The cancer-specific symptoms and heterogeneity in head and neck cancer cohorts make the identification of evidence-based exercise guidelines an important challenge for the future.

Only $9 \%$ of head and neck cancer survivors have been reported to meet physical activity guidelines after cancer diagnosis [16]. Encouraging exercise uptake and adherence should therefore be an important aspect of their clinical care. Establishing exercise preferences and perceived barriers are important in designing exercise programs that will facilitate uptake and adherence. Although these were previously investigated in the United States [14, 17], the findings were from relatively small samples and might not directly apply to the UK due to cultural and health-care system differences $[18,19]$. Another issue is that the percentage of head and neck cancer survivors who regularly engage in exercise is low [16], however, only $17 \%$ were reported to feel unable to engage in exercise [14]. Most therefore feel able to engage in regular exercise, but choose not to. An important avenue of enquiry in exploring this issue is establishing the extent to which exercise is perceived as beneficial, since weighing perceived benefits against perceived negative aspects of adopting a behaviour is an important step in deciding whether to adopt that behaviour [20]. Perceived exercise benefits among head and neck cancer survivors have not yet been investigated, however.

The main aim of the present study was to establish exercise preferences, barriers, and perceived benefits among a relatively large sample of head and neck cancer survivors in the UK. A secondary aim was to investigate the level of interest in participating in an exercise program for head and neck cancer survivors, as well as factors associated with between-subject differences in the level of interest.

\section{Methods}

\section{Participants}

University Hospital Aintree is the largest single centre head and neck cancer unit in the UK and in a geographical location with the fourth highest multiple index of deprivation in England [21]. A cohort of patients treated for primary squamous cell carcinoma of the head and neck at the hospital between 2010 and 2014 was identified from the hospital head and neck cancer database. Patients with cutaneous and salivary gland malignancy, patients treated with palliative intent, and patients with recurrence and ongoing disease were excluded. Patients were at least 18 years of age, without known dementia, or other mental condition that could affect their ability to complete the questionnaires used in the study. Mortality status was checked and in February 2016 postal questionnaire packs were sent to all patients known to be alive and disease-free, with reminders sent to nonresponders 4 weeks later. Electronic records provided information on clinical characteristics, such as age, gender, year of diagnosis, and treatment. The study received favourable opinion from the Cambridge South NHS Research Ethics Committee (Ref. 15/EE/0429).

\section{Questionnaire pack}

The questionnaire pack contained a covering letter about the survey, instructions on completing the questionnaires, a stamped addressed envelope for return, and the following six questionnaires: (1) exercise preferences; (2) perceived exercise benefits [22]; (3) exercise barriers [17]; (4) Godin leisure time exercise questionnaire [23]; (5) University of Washington quality of life (UW-QoL) Questionnaire version 4 [24]; and (6) 'Other information'. The Exercise Preferences questionnaire asked whether participants would be able to participate in an exercise program for head and neck cancer survivors and whether they would be interested in participating. Respondents declaring an interest were asked to answer questions regarding exercise preferences for frequency, intensity, time, and type of exercise, preference for starting the exercise program in relation to the timing of their treatment, and preferred exercise program duration and locations. The perceived exercise benefits questionnaire asked "How do you feel regular physical exercise would/ does benefit you?" and provided a list of ten potential benefits previously used in a study involving breast cancer survivors [22]. Each benefit was scored on a Likert scale ranging from 0 (Strongly disagree) to 4 (Strongly agree). The exercise barriers questionnaire asked 'Regardless of whether you currently exercise, how often do you think the following does/would interfere with your ability to exercise?' 37 potential barriers were listed, 33 of which were taken from 
Rogers et al. [17]. The additional four barriers were depression/anxiety, feeding tube, difficulty drinking, and lack of transport. Responses were scored on a Likert scale ranging from 1 (Never) to 5 (Very often). The Godin leisure time exercise questionnaire is a validated measure of self-reported exercise in the community and establishes average weekly frequency of engagement in mild, moderate, and strenuous exercise performed for at least $15 \mathrm{~min}$ at a time [23]. The UW-QoL questionnaire data [24, 25] will be reported elsewhere. The 'other information' questionnaire asked about age at leaving full-time education, cancer treatment and any recurrence, presence of a feeding tube into the stomach, and co-morbidities.

\section{Statistical methods}

The Chi-squared test was used to compare three groups of respondents (yes interested in participation, maybe interested in participation, not interested in participation) in regard to perceived exercise benefits, exercise barriers, intensity of weekly leisure time exercise, demographic and clinical factors. Statistical significance was accepted as $p<0.05$. Analyses were performed using SPSS v19 (SPSS Inc., Chicago, IL).

\section{Results}

The survey sample (January 2010-October 2014) comprised 1021 eligible head and neck cancer survivors of which 437 (43\%) responded, although 7 of these were omitted from the analyses due to scarcity of questionnaire responses. Lower response was noted for participants aged under 55 years (29\%) and over 85 years $(36 \%)$, but the response was typically $36-50 \%$ with no obvious biases when stratified by gender, time from diagnosis, tumour site, squamous cell carcinoma diagnosis, clinical TN staging, treatment group and surgical free-flap status. Median (IQR) time from cancer diagnosis to survey was 43 (30-58) months. The median (IQR) age at survey was $66(60-73)$ years and men accounted for $74 \%$ (317/430) of respondents. Primary tumours were oral $(28 \%, 122)$, laryngeal $(20 \%, 86)$, oropharyngeal $(41 \%, 176)$ and others $(11 \%, 46)$. The clinical T stage of 27\% (113/421) was late (stages 3-4), and the clinical $\mathrm{N}$ stage of $39 \%$ (164/423) was positive. Primary diagnosis was squamous cell carcinoma for $90 \%$ (347/385). Primary treatment comprised surgery alone $(41 \%, 175)$, surgery with adjuvant radiotherapy/chemotherapy $(33 \%, 143)$, or primary chemo-radiotherapy alone $(26 \%, 112)$. Free-flaps were used from almost one quarter $(23 \%, 72 / 313)$ of surgical patients and $7 \%(30 / 418)$ of respondents stated they currently had a feeding tube into their stomach. Recurrence of head and neck cancer had occurred in $12 \%$ (51/415) of respondents.
Two-thirds $(67 \%, 269 / 399)$ were 16 years old when they left full-time education.

When asked if interested in participating in an exercise program for head and neck cancer survivors, 64\% (267/419) either stated 'Yes' $(30 \%, 124)$ or 'Maybe' $(34 \%, 143)$. Of those with strongest interest, 90\% (111/124) stated 'Yes' they would be able to participate, and $10 \%$ stated 'Maybe'. In those with lesser interest only 30\% (43/143) stated 'Yes' they would be able to participate. One-third of the 267 expressing interest had no preference for exercise frequency, with another third preferring 2 or 3 days per week (Table 1). About half (49\%) preferred a program of moderate intensity, with $20 \%$ unsure or having no preference. About half (48\%) felt physically able to exercise for $<30 \mathrm{~min}, 71 \%$ for $<60 \mathrm{~min}$ and only $8 \%$ for $\geq 60 \mathrm{~min}$, with $21 \%$ unsure or unstated. A similar response was observed for preferred exercise duration, with those less interested in participating preferring shorter exercising times, with $18 \%$ (vs 5\% in those with stronger interest) preferring $<15 \mathrm{~min}$. There was little enthusiasm for starting an exercise program before (3\%) or during treatment (2\%), with more support for starting within a year after treatment (17\%) and after 1 year (18\%). Most though either had no preference on when to start (30\%), or were unsure or did not state $(30 \%)$. Those more interested in participating felt able to start the exercise program earlier. Preferred program length was $\leq 12$ weeks for $26 \%$ and $>12$ weeks for $26 \%$, and $42 \%$ had no preference. Those with less interest in participating preferred shorter programs. The most preferred activities were walking (68\%), flexibility exercises (35\%), water activities/swimming (33\%), cycling (31\%), and weight machines (19\%). Home (55\%), outdoors (46\%) and health club/gym (33\%) were the most popular choices for where to regularly perform exercise. Those with less interest in participating were more likely to prefer exercising at home (65 vs 44\%) than in a health club or gym (21 vs $47 \%$ ).

The section on perceived benefits of regular physical exercise (Table 2) was answered by 95\% (254/267) of those expressing an interest in participating in an exercise program versus 78\% (118/152) of those not interested. The greatest perceived benefits were improving heart and lung fitness (84\%), improving health or reducing risk of disease (76\%) and building up muscle strength (75\%), and lowest for doing better on their job (34\%), feeling more attractive (37\%) and meeting new people $(45 \%)$. There was a clear trend for higher perceived benefits from those with more interest in participating. The biggest absolute disparities between those more and less interested were for depression, tension and stress, and self-esteem.

The section on barriers to exercise (Table 3) was answered by $98 \%$ (261/267) of those expressing an interest in participating in an exercise program and 78\% (118/152) of those not interested. The highest rates of scoring as 4 or 5 
Table 1 Exercise preferences of those interested in participating in an exercise program for head and neck cancer survivors

\begin{tabular}{|c|c|c|c|c|c|c|}
\hline & Intere & ipati & & & Total & \\
\hline & Yes ( & & Mayb & & & \\
\hline How many days of the week wo & o perfo & & & & & \\
\hline 1 & $7 \%$ & 9 & $11 \%$ & 16 & $9 \%$ & 25 \\
\hline 2 & $15 \%$ & 18 & $14 \%$ & 20 & $14 \%$ & 38 \\
\hline 3 & $20 \%$ & 25 & $20 \%$ & 28 & $20 \%$ & 53 \\
\hline 4 & $8 \%$ & 10 & $8 \%$ & 12 & $8 \%$ & 22 \\
\hline 5 & $10 \%$ & 13 & $3 \%$ & 4 & $6 \%$ & 17 \\
\hline 6 & - & 0 & $2 \%$ & 3 & $1 \%$ & 3 \\
\hline 7 & $10 \%$ & 12 & $1 \%$ & 1 & $5 \%$ & 13 \\
\hline No preference & $30 \%$ & 37 & $36 \%$ & 51 & $33 \%$ & 88 \\
\hline Not stated & - & 0 & $6 \%$ & 8 & $3 \%$ & 8 \\
\hline At what intensity would you like & & & & & & \\
\hline Light & $9 \%$ & 11 & $25 \%$ & 36 & $18 \%$ & 47 \\
\hline Moderate & $52 \%$ & 65 & $46 \%$ & 66 & $49 \%$ & 131 \\
\hline Vigorous & $17 \%$ & 21 & $6 \%$ & 8 & $11 \%$ & 29 \\
\hline No preference & $10 \%$ & 13 & $6 \%$ & 8 & $8 \%$ & 21 \\
\hline Not sure & $8 \%$ & 10 & $15 \%$ & 22 & $12 \%$ & 32 \\
\hline Not stated & $3 \%$ & 4 & $2 \%$ & 3 & $3 \%$ & 7 \\
\hline How long do you think you wou & lly able & or? & & & & \\
\hline$<15 \min$ & $12 \%$ & 15 & $23 \%$ & 33 & $18 \%$ & 48 \\
\hline $15-29 \mathrm{~min}$ & $31 \%$ & 38 & $29 \%$ & 42 & $30 \%$ & 80 \\
\hline $30-44 \mathrm{~min}$ & $19 \%$ & 24 & $12 \%$ & 17 & $15 \%$ & 41 \\
\hline $45-59 \mathrm{~min}$ & $10 \%$ & 12 & $6 \%$ & 9 & $8 \%$ & 21 \\
\hline$\geq 60 \min$ & $10 \%$ & 12 & $6 \%$ & 9 & $8 \%$ & 21 \\
\hline Not sure & $15 \%$ & 18 & $21 \%$ & 30 & $18 \%$ & 48 \\
\hline Not stated & $4 \%$ & 5 & $2 \%$ & 3 & $3 \%$ & 8 \\
\hline How long would you prefer to e & & & & & & \\
\hline$<15 \min$ & $5 \%$ & 6 & $18 \%$ & 26 & $12 \%$ & 32 \\
\hline $15-29 \mathrm{~min}$ & $36 \%$ & 45 & $31 \%$ & 45 & $34 \%$ & 90 \\
\hline $30-44 \mathrm{~min}$ & $17 \%$ & 21 & $10 \%$ & 15 & $13 \%$ & 36 \\
\hline $45-59 \mathrm{~min}$ & $13 \%$ & 16 & $6 \%$ & 9 & $9 \%$ & 25 \\
\hline$\geq 60 \min$ & $14 \%$ & 17 & $6 \%$ & 9 & $10 \%$ & 26 \\
\hline Not sure & $11 \%$ & 14 & $22 \%$ & 31 & $17 \%$ & 45 \\
\hline Not stated & $4 \%$ & 5 & $6 \%$ & 8 & $5 \%$ & 13 \\
\hline When would you feel able to sta & progra & & & & & \\
\hline Before treatment & $4 \%$ & 5 & $2 \%$ & 3 & $3 \%$ & 8 \\
\hline During treatment & $2 \%$ & 3 & $2 \%$ & 3 & $2 \%$ & 6 \\
\hline $0-6$ months after treatment & $18 \%$ & 22 & $5 \%$ & 7 & $11 \%$ & 29 \\
\hline $7-12$ months after treatment & $9 \%$ & 11 & $3 \%$ & 5 & $6 \%$ & 16 \\
\hline 1 year or more after treatment & $17 \%$ & 21 & $20 \%$ & 28 & $18 \%$ & 49 \\
\hline No preference & $26 \%$ & 32 & $33 \%$ & 47 & $30 \%$ & 79 \\
\hline Not sure & $15 \%$ & 18 & $29 \%$ & 41 & $22 \%$ & 59 \\
\hline Not stated & $10 \%$ & 12 & $6 \%$ & 9 & $8 \%$ & 21 \\
\hline How long would you like the ex & $\mathrm{n}$ to las & & & & & \\
\hline Less than 6 weeks & $9 \%$ & 11 & $18 \%$ & 26 & $14 \%$ & 37 \\
\hline $7-12$ weeks & $10 \%$ & 12 & $15 \%$ & 21 & $12 \%$ & 33 \\
\hline More than 12 weeks & $40 \%$ & 49 & $15 \%$ & 21 & $26 \%$ & 70 \\
\hline No preference & $37 \%$ & 46 & $46 \%$ & 66 & $42 \%$ & 112 \\
\hline Not stated & $5 \%$ & 6 & $6 \%$ & 9 & $6 \%$ & 15 \\
\hline
\end{tabular}


Table 1 (continued)

\begin{tabular}{|c|c|c|c|c|c|c|}
\hline \multirow{2}{*}{\multicolumn{2}{|c|}{$\begin{array}{l}\text { Stated for } \\
\text { What type of activities would you like to perform? }\end{array}$}} & & \multicolumn{2}{|c|}{$N=134$} & \multicolumn{2}{|c|}{$N=254$} \\
\hline & & & & & & \\
\hline Walking & $73 \%$ & 87 & $64 \%$ & 86 & $68 \%$ & 173 \\
\hline Flexibility exercises & $49 \%$ & 59 & $23 \%$ & 31 & $35 \%$ & 90 \\
\hline Water activities/swimming & $40 \%$ & 48 & $27 \%$ & 36 & $33 \%$ & 84 \\
\hline Cycling & $43 \%$ & 51 & $21 \%$ & 28 & $31 \%$ & 79 \\
\hline Weight machines & $26 \%$ & 31 & $12 \%$ & 16 & $19 \%$ & 47 \\
\hline Yoga & $20 \%$ & 24 & $8 \%$ & 11 & $14 \%$ & 35 \\
\hline Free weights & $21 \%$ & 25 & $7 \%$ & 9 & $13 \%$ & 34 \\
\hline Resistance bands & $18 \%$ & 22 & $6 \%$ & 8 & $12 \%$ & 30 \\
\hline Tai Chi & $16 \%$ & 19 & $7 \%$ & 10 & $11 \%$ & 29 \\
\hline Pilates & $14 \%$ & 17 & $5 \%$ & 7 & $9 \%$ & 24 \\
\hline Circuit training & $16 \%$ & 19 & $3 \%$ & 4 & $9 \%$ & 23 \\
\hline Sport & $10 \%$ & 12 & $5 \%$ & 7 & $7 \%$ & 19 \\
\hline Other $^{\mathrm{a}}$ & $15 \%$ & 18 & $7 \%$ & 9 & $11 \%$ & 27 \\
\hline No preference & $5 \%$ & 6 & $13 \%$ & 18 & $9 \%$ & 24 \\
\hline Stated for & \multicolumn{2}{|c|}{$N=119$} & \multicolumn{2}{|c|}{$N=139$} & \multicolumn{2}{|c|}{$N=258$} \\
\hline \multicolumn{7}{|c|}{ Where would you like to exercise on a regular basis? } \\
\hline Home & $44 \%$ & 52 & $65 \%$ & 91 & $55 \%$ & 143 \\
\hline Outdoors & $48 \%$ & 57 & $45 \%$ & 62 & $46 \%$ & 119 \\
\hline Health club/gym & $47 \%$ & 56 & $21 \%$ & 29 & $33 \%$ & 85 \\
\hline Hospital centre & $17 \%$ & 20 & $7 \%$ & 10 & $12 \%$ & 30 \\
\hline Community centre & $15 \%$ & 18 & $5 \%$ & 7 & $10 \%$ & 25 \\
\hline Work & $2 \%$ & 2 & $1 \%$ & 1 & $1 \%$ & 3 \\
\hline Other $^{\mathrm{b}}$ & $4 \%$ & 5 & $4 \%$ & 6 & $4 \%$ & 11 \\
\hline No preference & $12 \%$ & 14 & $9 \%$ & 13 & $10 \%$ & 27 \\
\hline
\end{tabular}

${ }^{a}$ Other activities included (number of respondents in parentheses): treadmill exercise/running (6), rowing (4), golf (4), crown green bowling (3), dancing (3), gardening (3), boxing (1), croquet (1), indoor climbing (1), indoor skiing (1), table tennis (1), trampoline (1), Zumba (1)

${ }^{\mathrm{b}}$ Other locations included (number of respondents in parentheses): swimming pool (4), dance school/hall (2), golf course (2), bowling green (1), countryside and coast (1), park (1)

Table 2 Perceived exercise benefits of regular physical exercise, for the total sample, and by how interested respondents were in participating in an exercise program

\begin{tabular}{|c|c|c|c|c|c|c|c|}
\hline & \multicolumn{2}{|c|}{$\begin{array}{l}\text { Agree or } \\
\text { strongly agree } \\
\text { with statement }\end{array}$} & \multirow[t]{2}{*}{ Mean score ${ }^{a}$} & \multicolumn{3}{|c|}{$\%$ Agree or strongly agree } & \multirow[t]{2}{*}{$\begin{array}{l}\text { Chi-squared } \\
\text { test ( } 3 \text { groups) } \\
p \text { value }\end{array}$} \\
\hline & $\%$ & $N$ & & $\begin{array}{l}\text { Yes, interested } \\
\text { in participation }\end{array}$ & $\begin{array}{l}\text { Maybe interested } \\
\text { in participation }\end{array}$ & $\begin{array}{l}\text { Not interested } \\
\text { in participation }\end{array}$ & \\
\hline 1. Improve my heart and lung fitness & 84 & $301 / 358$ & 3.1 & 90 & 85 & 77 & 0.03 \\
\hline $\begin{array}{l}\text { 2. Improve my health or reduce my } \\
\text { risk of disease }\end{array}$ & 76 & $269 / 354$ & 2.9 & 84 & 77 & 68 & 0.02 \\
\hline 3. Build up my muscle strength & 75 & $267 / 354$ & 2.9 & 91 & 73 & 62 & $<0.001$ \\
\hline 4. Lose weight or improve my shape & 64 & $224 / 348$ & 2.7 & 77 & 61 & 55 & 0.002 \\
\hline 5. Feel less tension and stress & 64 & $226 / 352$ & 2.7 & 81 & 63 & 49 & $<0.001$ \\
\hline 6. Improve my self-esteem & 62 & $220 / 354$ & 2.7 & 79 & 59 & 47 & $<0.001$ \\
\hline 7. Feel less depressed & 56 & $200 / 357$ & 2.6 & 75 & 54 & 39 & $<0.001$ \\
\hline 8. Meet new people & 45 & $160 / 352$ & 2.4 & 59 & 37 & 40 & 0.001 \\
\hline 9. Feel more attractive & 37 & $130 / 347$ & 2.2 & 50 & 34 & 28 & 0.003 \\
\hline 10. Do better on my job & 34 & $105 / 312$ & 2.1 & 46 & 29 & 27 & 0.005 \\
\hline
\end{tabular}

${ }^{\mathrm{a}}$ On a $0-4$ scale, with $0=$ strongly disagree, $1=$ disagree, $2=$ neither agree nor disagree, $3=$ agree, $4=$ strongly agree 
(very often) on the 5-point barriers scale were for dry mouth or throat $(40 \%)$, fatigue $(37 \%)$, shortness of breath $(30 \%)$, muscle weakness (28\%), and difficulty swallowing $(25 \%)$, with rates for another 13 issues ranging between 20 and $24 \%$. Those not interested in participating were more likely to cite 'lack of enjoyment', 'exercise not a priority', 'exercise is boring' and 'lack of interest' as barriers to exercise. They also were less likely to cite 'lack of equipment' and 'lack of facilities and/or space'. Otherwise, the potential barriers were similar regardless of interest in participation.

Further analysis focussed on identifying factors associated with interest in participation. These included current leisure time exercise of $>15$ min' duration one or more times a week, quality of life status, and current clinical and demographic factors. Engagement in strenuous exercise was reported by $12 \%(51 / 430)$, with median (IQR) duration 60 (30-75) min, moderate exercise by 24\% (104/428), median (IQR) duration 45 (30-60) min, and mild exercise by $52 \%$ (218/417), with median (IQR) duration 40 (30-90) min. One-third $(35 \%, 146 / 416)$ did no exercise for $>15 \mathrm{~min}$ during their free-time, and of those that did, their median (IQR) weekly leisure activity score was 21 (12-30). Greater current engagement in more intense exercise was associated with greater interest in participating in an exercise program (Table 4), ranging from $52 \%$ interest if doing strenuous exercise to $23 \%$ if doing no exercise.

Participant age was a strong indicator of interest in program participation (Table 5), with more than half of those aged $>75$ years not being interested. There were no notable associations regarding gender and clinical factors (tumour location, staging, diagnosis \& treatment, time from diagnosis) pertaining at the time of primary diagnosis (results not shown). Those whose cancer had returned and those who had chemotherapy showed more interest in participation. Nearly half (48\%) stated one or more medical conditions that could impact on their ability to perform exercise and this group had slightly more interest in participating than those not stating any conditions. The three main groups of conditions were joint/mobility-related (92 participants), heartrelated (49) and lung-related (46), though for the latter there was less interest in participating.

\section{Discussion}

The main aim of the present study was to establish exercise preferences, barriers, and perceived benefits among a relatively large sample of head and neck cancer survivors in the UK. A secondary aim was to investigate the level of interest in participating in an exercise program for head and neck cancer survivors, as well as the factors associated with between-subject differences in level of interest. Main findings were that $64 \%$ of respondents expressed an interest in participating in an exercise program, with greater interest associated with younger age, lower social-emotional aspects of quality of life, absence of lung-related co-morbidity, greater current levels of physical activity, greater perceived exercise benefits, and lower scores on certain barriers to exercise. Exercise preferences were diverse; however, the most popular were a frequency of three times per week, moderate-intensity, 15-29 min per bout, and consisting of walking, swimming, cycling, and flexibility and resistance training exercises. The most commonly cited exercise barriers were symptoms specific to head and neck cancer.

The $30 \%$ of respondents in the present study interested and $34 \%$ maybe interested in participating in an exercise program were similar to the 33 and $38 \%$, respectively, reported by Rogers et al. [14] for 90 head and neck cancer survivors in the USA. Encouragingly, the most popular exercise program preferences were relatively consistent with current cancer physical activity guidelines [5-7]. A notable exception is that a higher frequency and/or duration would be needed to accumulate the recommended minimum of $150 \mathrm{~min}$ of moderate intensity 'aerobic' exercise and resistance training on at least 2 days per week $[6,7]$. The most popular exercise preferences are useful for designing group-based exercise programs delivered in the community, which dominate the current 312 registered UK cardiac rehabilitation programs [26]. Exercise preferences in the present study were diverse, however, particularly between those more versus less interested in participating in an exercise program. These results emphasise the importance of individuality as a fitness training principle [27] when designing exercise programs for head and neck cancer survivors. Of note is that $55 \%$ of interested respondents preferred to exercise at home, with relatively few preferring to exercise in a community (10\%) or hospital (12\%) centre. This is consistent with a previous observation that $82 \%$ of head and neck cancer survivors who showed a preference, favoured unsupervised rather than supervised exercise [14]. The UK cardiac model of group-based exercise programs delivered in a community setting, with home-based programs accounting for only $10 \%$ of the total [26], may not therefore be an effective strategy for exercise program design in head and neck cancer survivors. Further support for home-based programs is that no differences in outcomes have been observed between home-based and centre-based exercise programs [28]. There has been a growing interest in telehealth for the remote delivery of exercise programs in clinical populations (e.g., [29]). This may be a particularly effective strategy for delivering home-based exercise programs in head and neck cancer survivors in the UK, given the large distances many head and neck cancer survivors would need to travel to attend their nearest rehabilitation centre. 
Table 3 Exercise barriers for the total sample and by how interested respondents were in participating in an exercise program

\begin{tabular}{|c|c|c|c|c|c|c|c|c|c|}
\hline \multirow{2}{*}{$\begin{array}{l}\text { Regardless of whether } \\
\text { you currently exercise, } \\
\text { how often do you think } \\
\text { the following does/ } \\
\text { would interfere with } \\
\text { your ability to exercise? }\end{array}$} & \multirow[t]{2}{*}{$N$} & \multicolumn{4}{|c|}{ Barriers scale } & \multicolumn{3}{|c|}{$\%$ Scoring $4-5$ on the barriers scale } & \multirow{2}{*}{$\begin{array}{l}\text { Chi-squared test } \\
p \text { value }\end{array}$} \\
\hline & & $\begin{array}{l}\% \\
1=\text { never } \\
\text { or } 2\end{array}$ & $\% 3$ & $\begin{array}{l}\% 4 \text { or } \\
5=\text { very } \\
\text { often }\end{array}$ & Mean score $^{a}$ & $\begin{array}{l}\text { Yes, interested } \\
\text { in participation }\end{array}$ & $\begin{array}{l}\text { Maybe inter- } \\
\text { ested in partici- } \\
\text { pation }\end{array}$ & $\begin{array}{l}\text { Not interested } \\
\text { in participa- } \\
\text { tion }\end{array}$ & \\
\hline 1. Dry mouth or throat & 364 & 46 & 14 & 40 & 2.9 & 40 & 44 & 38 & 0.67 \\
\hline 2. Fatigue & 350 & 34 & 29 & 37 & 3.0 & 33 & 33 & 42 & 0.29 \\
\hline 3 Shortness of breath & 338 & 53 & 17 & 30 & 2.6 & 27 & 35 & 27 & 0.31 \\
\hline 4. Muscle weakness & 338 & 51 & 22 & 28 & 2.6 & 25 & 28 & 29 & 0.75 \\
\hline 5. Difficulty swallowing & 343 & 62 & 13 & 25 & 2.3 & 26 & 26 & 23 & 0.85 \\
\hline $\begin{array}{l}\text { 6. Shoulder weakness } \\
\text { and/or pain }\end{array}$ & 337 & 61 & 15 & 24 & 2.3 & 29 & 21 & 21 & 0.26 \\
\hline $\begin{array}{l}\text { 7. Drainage in mouth } \\
\text { or throat }\end{array}$ & 315 & 62 & 15 & 23 & 2.2 & 24 & 23 & 19 & 0.65 \\
\hline $\begin{array}{l}\text { 8. Lack of self-disci- } \\
\text { pline }\end{array}$ & 323 & 50 & 28 & 23 & 2.5 & 22 & 22 & 26 & 0.73 \\
\hline 9. Pain & 331 & 64 & 13 & 23 & 2.2 & 23 & 24 & 21 & 0.91 \\
\hline 10. Difficulty breathing & 335 & 60 & 18 & 22 & 2.3 & 22 & 23 & 20 & 0.90 \\
\hline $\begin{array}{l}\text { 11. Lack of facilities } \\
\text { and/or space }\end{array}$ & 324 & 56 & 22 & 22 & 2.4 & 24 & 29 & 9 & 0.002 \\
\hline 12. Difficulty eating & 336 & 64 & 14 & 21 & 2.2 & 17 & 24 & 22 & 0.46 \\
\hline 13. Lack of equipment & 319 & 56 & 23 & 21 & 2.3 & 24 & 26 & 9 & 0.006 \\
\hline 14. Weather & 331 & 51 & 28 & 21 & 2.5 & 17 & 25 & 19 & 0.29 \\
\hline $\begin{array}{l}\text { 15. Inconvenient exer- } \\
\text { cise schedule }\end{array}$ & 314 & 51 & 29 & 21 & 2.5 & 14 & 27 & 20 & 0.06 \\
\hline $\begin{array}{l}\text { 16. Exercise not in } \\
\text { routine }\end{array}$ & 325 & 51 & 28 & 21 & 2.5 & 16 & 24 & 24 & 0.30 \\
\hline $\begin{array}{l}\text { 17. Exercise not a } \\
\text { priority }\end{array}$ & 335 & 51 & 29 & 20 & 2.5 & 16 & 15 & 29 & 0.02 \\
\hline 18. Lack of enjoyment & 337 & 53 & 27 & 20 & 2.5 & 15 & 19 & 29 & 0.05 \\
\hline 19. Procrastination & 279 & 53 & 27 & 19 & 2.4 & 22 & 19 & 16 & 0.59 \\
\hline 20. Lack of time & 323 & 59 & 22 & 19 & 2.3 & 19 & 20 & 17 & 0.87 \\
\hline $\begin{array}{l}\text { 21. Lack of knowledge- } \\
\text { able exercise staff }\end{array}$ & 316 & 64 & 18 & 19 & 2.2 & 23 & 20 & 13 & 0.16 \\
\hline 22. Lack of interest & 342 & 53 & 29 & 18 & 2.4 & 9 & 18 & 26 & 0.007 \\
\hline 23. Exercise is boring & 326 & 58 & 24 & 18 & 2.4 & 13 & 18 & 26 & 0.04 \\
\hline $\begin{array}{l}\text { 24. Decreased food } \\
\text { intake }\end{array}$ & 326 & 64 & 17 & 18 & 2.2 & 15 & 18 & 21 & 0.49 \\
\hline 25. Cost & 332 & 66 & 17 & 17 & 2.1 & 23 & 17 & 11 & 0.09 \\
\hline $\begin{array}{l}\text { 26. Family responsi- } \\
\text { bilities }\end{array}$ & 328 & 66 & 18 & 16 & 2.1 & 15 & 19 & 10 & 0.20 \\
\hline 27. Lack of transport & 333 & 76 & 9 & 15 & 1.8 & 13 & 16 & 16 & 0.70 \\
\hline 28. Cough & 334 & 71 & 15 & 14 & 2.0 & 9 & 16 & 16 & 0.26 \\
\hline $\begin{array}{l}\text { 29. Fear of making con- } \\
\text { dition worse }\end{array}$ & 329 & 74 & 12 & 14 & 1.9 & 9 & 18 & 14 & 0.14 \\
\hline 30. Depression/anxiety & 326 & 73 & 12 & 14 & 1.9 & 10 & 14 & 16 & 0.38 \\
\hline 31. Difficulty drinking & 330 & 81 & 7 & 12 & 1.6 & 11 & 11 & 14 & 0.76 \\
\hline 32. Fear of injury & 329 & 76 & 12 & 12 & 1.9 & 11 & 14 & 12 & 0.77 \\
\hline $\begin{array}{l}\text { 33. Difficulty commu- } \\
\text { nicating }\end{array}$ & 330 & 78 & 12 & 11 & 1.7 & 11 & 11 & 10 & 0.94 \\
\hline 34. Lack of company & 327 & 75 & 14 & 11 & 1.8 & 12 & 14 & 6 & 0.14 \\
\hline 35. Lack of skills & 323 & 72 & 16 & 11 & 1.9 & 11 & 9 & 13 & 0.68 \\
\hline 36. Feeding tube & 321 & 88 & 3 & 10 & 1.4 & 12 & 8 & 9 & 0.57 \\
\hline
\end{tabular}


Table 3 (continued)

\begin{tabular}{|c|c|c|c|c|c|c|c|c|c|}
\hline \multirow{2}{*}{$\begin{array}{l}\text { Regardless of whether } \\
\text { you currently exercise, } \\
\text { how often do you think } \\
\text { the following does/ } \\
\text { would interfere with } \\
\text { your ability to exercise? }\end{array}$} & \multirow[t]{2}{*}{$N$} & \multicolumn{4}{|c|}{ Barriers scale } & \multicolumn{3}{|c|}{$\%$ Scoring $4-5$ on the barriers scale } & \multirow{2}{*}{$\begin{array}{l}\text { Chi-squared test } \\
p \text { value }\end{array}$} \\
\hline & & $\begin{array}{l}\% \\
1=\text { never } \\
\text { or } 2\end{array}$ & $\% 3$ & $\begin{array}{l}\% 4 \text { or } \\
5=\text { very } \\
\text { often }\end{array}$ & Mean score ${ }^{\mathrm{a}}$ & $\begin{array}{l}\text { Yes, interested } \\
\text { in participation }\end{array}$ & $\begin{array}{l}\text { Maybe inter- } \\
\text { ested in partici- } \\
\text { pation }\end{array}$ & $\begin{array}{l}\text { Not interested } \\
\text { in participa- } \\
\text { tion }\end{array}$ & \\
\hline 37. Nausea & 328 & 77 & 13 & 10 & 1.7 & 9 & 8 & 11 & 0.79 \\
\hline
\end{tabular}

${ }^{\text {a } O n ~ a ~ 1-5 ~ s c a l e, ~ t h e ~ h i g h e r ~ t h e ~ s c o r e ~ t h e ~ g r e a t e r ~ t h e ~ p e r c e i v e d ~ b a r r i e r ~}$

Table 4 Intensity of weekly leisure time exercise by how interested respondents were in participating in an exercise program

\begin{tabular}{|c|c|c|c|c|c|c|c|c|}
\hline \multirow[b]{2}{*}{ Strenuous exercise $^{\mathrm{a}}$ of $>15$ min duration one or more times a week } & \multirow{2}{*}{$\begin{aligned} \frac{N}{5} \\
50\end{aligned}$} & \multicolumn{2}{|c|}{$\begin{array}{l}\text { Yes, inter- } \\
\text { ested in } \\
\text { participation }\end{array}$} & \multicolumn{2}{|c|}{$\begin{array}{l}\text { Maybe } \\
\text { interested in } \\
\text { participation }\end{array}$} & \multicolumn{2}{|c|}{$\begin{array}{l}\text { Not interested } \\
\text { in participa- } \\
\text { tion }\end{array}$} & \multirow{2}{*}{$\begin{array}{l}\text { Chi-squared test } \\
p \text { value } \\
0.002\end{array}$} \\
\hline & & $52 \%$ & 26 & $26 \%$ & 13 & $22 \%$ & 11 & \\
\hline $\begin{array}{l}\text { No strenuous exercise but moderate exercise of }>15 \text { min duration one } \\
\text { or more times a week }\end{array}$ & 76 & $38 \%$ & 29 & $34 \%$ & 26 & $28 \%$ & 21 & \\
\hline $\begin{array}{l}\text { No strenuous or moderate exercise but any mild exercise of }>15 \mathrm{~min} \\
\text { duration one or more times a week }\end{array}$ & 141 & $26 \%$ & 36 & $35 \%$ & 50 & $39 \%$ & 55 & \\
\hline None of the above & 141 & $23 \%$ & 32 & $35 \%$ & 49 & $43 \%$ & 60 & \\
\hline \multicolumn{9}{|l|}{ Godin weekly leisure activity score ${ }^{\mathrm{b}}$} \\
\hline 0 & 141 & $23 \%$ & 32 & $35 \%$ & 49 & $43 \%$ & 60 & 0.007 \\
\hline $1-9$ & 60 & $27 \%$ & 16 & $35 \%$ & 21 & $38 \%$ & 23 & \\
\hline $10-19$ & 63 & $33 \%$ & 21 & $32 \%$ & 20 & $35 \%$ & 22 & \\
\hline $20-29$ & 75 & $25 \%$ & 19 & $40 \%$ & 30 & $35 \%$ & 26 & \\
\hline$\geq 30$ & 68 & $51 \%$ & 35 & $25 \%$ & 17 & $24 \%$ & 16 & \\
\hline
\end{tabular}

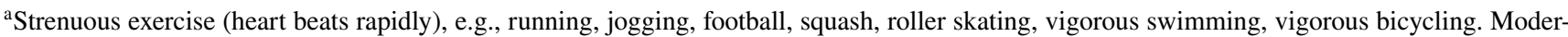
ate exercise (not exhausting), e.g., fast walking, tennis, easy bicycling, badminton, easy swimming, dancing. Mild exercise (minimal effort), e.g., easy walking, yoga, fishing, bowling, golf

${ }^{b}$ Weekly leisure activity score $(\mathrm{T})$ calculated from weekly frequencies of strenuous, moderate, and mild activities as follows: $\mathrm{T}=(9 \times \mathrm{Strenuous})$ $+(5 \times$ Moderate $)+(3 \times$ mild $)$

The most commonly cited exercise barriers in the present study were dry mouth or throat, fatigue, shortness of breath, muscle weakness, difficulty swallowing, and shoulder weakness and pain, which are all dominant symptoms associated with head and neck cancer $[10,12]$. These findings are largely consistent with those of Rogers et al. [16], but contrast with those reported for the general adult population, where lack of time and motivation dominate (e.g. [30]). Given the considerable benefits that head and neck cancer survivors can expect from exercise engagement [31], these findings emphasise the importance of providing advice on how to negate or manage disease-specific exercise barriers during standard clinical care. Dry mouth/throat was the most common barrier to exercise expressed by participants in the present study and caregivers should be particularly mindful of the management of these [32], as well as providing advice regarding avoidance of exercise in cold air to prevent exacerbating symptoms [33].
Little research has investigated the perceived benefits of exercise in cancer survivors and, to the best of our knowledge, none has investigated perceived benefits amongst head and neck cancer survivors. The mean values for perceived exercise benefits observed in the present study were lower on all ten items than reported by Spector et al. [22] for breast cancer survivors. The mean values for doing better on my job, improving body shape, feeling more attractive, and meeting new people were the lowest and represented the greatest negative difference compared to those reported by Spector et al. [22]. This might reflect gender differences in perceptions, since $74 \%$ of respondents in the present study were men compared to all women in the study by Spector et al. [22]. In the present study, level of interest in participating in an exercise program was positively associated with perceived benefits. This is consistent with the transtheoretical model of behaviour change, which postulates that perceived benefits are important in favourably modifying the decisional balance of the relative 
Table 5 Demographic and clinical factors at time of survey by how interested respondents were in participating in an exercise program

\begin{tabular}{|c|c|c|c|c|c|}
\hline & Participants & $\begin{array}{l}\% \text { Yes, inter- } \\
\text { ested in partici- } \\
\text { pation }\end{array}$ & $\begin{array}{l}\% \text { Maybe } \\
\text { interested in } \\
\text { participation }\end{array}$ & $\begin{array}{l}\% \text { Not inter- } \\
\text { ested in partici- } \\
\text { pation }\end{array}$ & $\begin{array}{l}\text { Chi-squared test } \\
p \text { value }\end{array}$ \\
\hline \multicolumn{6}{|l|}{ Age at survey } \\
\hline$<55$ & 46 & 46 & 37 & 17 & \multirow[t]{5}{*}{0.002} \\
\hline $55-64$ & 140 & 35 & 34 & 31 & \\
\hline $65-74$ & 153 & 25 & 37 & 38 & \\
\hline $75-79$ & 49 & 24 & 22 & 53 & \\
\hline$\geq 80$ & 31 & 13 & 35 & 52 & \\
\hline \multicolumn{6}{|l|}{ Age at leaving full-time education } \\
\hline 16 & 261 & 29 & 33 & 38 & \multirow[t]{4}{*}{0.40} \\
\hline $17-18$ & 54 & 24 & 44 & 31 & \\
\hline $19-22$ & 35 & 40 & 29 & 31 & \\
\hline Older than 22 & 40 & 38 & 35 & 28 & \\
\hline \multicolumn{6}{|c|}{ Has head and neck cancer ever recurred (ever come back) } \\
\hline Yes & 48 & 42 & 38 & 21 & \multirow[t]{2}{*}{0.04} \\
\hline No & 356 & 28 & 34 & 38 & \\
\hline \multicolumn{6}{|l|}{ Ever had surgery as part of cancer treatment } \\
\hline Yes & 315 & 30 & 36 & 35 & \multirow[t]{2}{*}{0.54} \\
\hline No & 94 & 29 & 31 & 40 & \\
\hline \multicolumn{6}{|c|}{ Ever had radiotherapy as part of cancer treatment } \\
\hline Yes & 283 & 30 & 35 & 35 & \multirow[t]{2}{*}{0.72} \\
\hline No & 122 & 27 & 34 & 39 & \\
\hline \multicolumn{6}{|c|}{ Ever had chemotherapy as part of cancer treatment } \\
\hline Yes & 112 & 38 & 33 & 29 & \multirow[t]{2}{*}{0.03} \\
\hline No & 293 & 26 & 35 & 39 & \\
\hline \multicolumn{6}{|c|}{ Do you have a feeding tube into your stomach at the moment } \\
\hline Yes & 28 & 43 & 25 & 32 & \multirow[t]{2}{*}{0.23} \\
\hline No & 379 & 28 & 35 & 37 & \\
\hline \multicolumn{6}{|c|}{ What other medical conditions do you have that could impact on you being able to perform exercise } \\
\hline Condition(s) stated & 199 & 31 & 38 & 31 & \multirow[t]{2}{*}{0.12} \\
\hline None stated & 219 & 28 & 31 & 41 & \\
\hline $\begin{array}{l}\text { Heart related: e.g., IHD, attack, BP, } \\
\mathrm{AF} \text {, angina }\end{array}$ & 49 & 35 & 41 & 24 & 0.20 versus condition not stated \\
\hline $\begin{array}{l}\text { Lung related: e.g. COPD, asthma, } \\
\text { SOB }\end{array}$ & 46 & 17 & 54 & 28 & 0.008 versus condition not stated \\
\hline $\begin{array}{l}\text { Joint/mobility related: e.g., arthritis, } \\
\text { hip/knee replacement, osteoporosis, } \\
\text { mobility or balance issues, sciatica }\end{array}$ & 92 & 32 & 32 & 37 & 0.82 versus condition not stated \\
\hline
\end{tabular}

weighing of the positive and negative aspects of changing [20]. Of note is that only $13 \%$ of participants interested in participating in an exercise program, who also expressed a preference of when they would have felt able to start, felt able to start the program before or during cancer treatment. This is despite mounting evidence of the physical and psychological benefits of exercise before [34] and during treatment $[1,3]$. These findings suggest that educating head and neck cancer survivors on the potential benefits of exercise should be an integral part of standard clinical care and should ideally be undertaken soon after time of diagnosis.

To our knowledge, this is the first study to investigate exercise preferences, barriers, and perceived benefits in a relativity large sample of head and neck cancer survivors, and the first in the UK. A limitation of the study was the poor questionnaire response rate of $43 \%$, which is likely somewhat related to the burden of responding to multiple questionnaires in the questionnaire pack. It is also plausible that non-responders were less likely to have been physically 
active, or interested in participating in an exercise program for head and neck cancer survivors.

\section{Conclusion}

These findings provide exercise preferences to guide exercise program design for head and neck cancer survivors. Exercise barriers specific to head and neck cancer were commonly cited and need addressing to promote exercise uptake and adherence. The need for education on the potential benefits of exercise to promote greater exercise uptake and adherence also was apparent, particularly for those not interested or less interested in participating in an exercise program.

Acknowledgements The authors are sincerely grateful to all participants who gave up their time to make this study possible and to the Patient and Carers Research Forum at University Hospital Aintree for their feedback and advice during the design of the study and on the content of the questionnaire pack. We also thanks Joanne Earley for identifying eligible patients on the hospital database and for posting the questionnaire packs.

\section{Compliance with ethical standards}

Conflict of interest All authors declare that they have no conflicts of interest regarding this article.

Ethical approval All procedures performed in this study involving human participants were in accordance with the ethical standards of the institutional and/or national research committee and with the 1964 Helsinki Declaration and its later amendments or comparable ethical standards. This article does not contain any studies with animals performed by any of the authors.

Informed consent Informed consent was obtained from all individual participants included in the study.

Open Access This article is distributed under the terms of the Creative Commons Attribution 4.0 International License (http://creativecommons.org/licenses/by/4.0/), which permits unrestricted use, distribution, and reproduction in any medium, provided you give appropriate credit to the original author(s) and the source, provide a link to the Creative Commons license, and indicate if changes were made.

\section{References}

1. Speck RM, Courneya KS, Mâsse LC, Duval S, Schmitz KH (2010) An update of controlled physical activity trials in cancer survivors: a systematic review and meta-analysis. J Cancer Surviv 4(2):87-100

2. Tomlinson D, Diorio C, Beyene J, Sung L (2014) Effect of exercise on cancer-related fatigue: a meta-analysis. Am J Phys Med Rehabil 93(8):675-686

3. Gerritsen JK, Vincent AJ (2016) Exercise improves quality of life in patients with cancer: a systematic review and meta-analysis of randomised controlled trials. Br J Sports Med 50(13):796-803
4. Ballard-Barbash R, Friedenreich CM, Courneya KS, Siddiqi SM, McTiernan A, Alfano CM (2012) Physical activity, biomarkers, and disease outcomes in cancer survivors: a systematic review. J Natl Cancer Inst 104(11):815-840

5. Hayes SC, Spence RR, Galvão DA, Newton RU (2009) Australian Association for Exercise and Sports Science position stand: optimising cancer outcomes through exercise. J Sci Med Sport 12(4):428-434

6. Schmitz KH, Courneya KS, Matthews C, Demark-Wahnefried W, Galvão DA, Pinto BM et al (2010) American College of Sports Medicine roundtable on exercise guidelines for cancer survivors. Med Sci Sports Exerc 42(7):1409-1426

7. Rock CL, Doyle C, Demark-Wahnefried W, Meyerhardt J, Courneya KS, Schwartz AL et al (2012) Nutrition and physical activity for cancer survivors. CA Cancer J Clin 62(4):243-274

8. NICE (2004) Improving outcomes in head and neck cancers: the manual. National Institute for Clinical Excellence, London

9. Jemal A, Bray F, Center MM, Ferlay J, Ward E, Forman D (2011) Global cancer statistics. CA Cancer J Clin 61(2):69-90

10. Lokker ME, Offerman MP, van der Velden LA, de Boer MF, Pruyn JF, Teunissen SC (2013) Symptoms of patients with incurable head and neck cancer: prevalence and impact on daily functioning. Head Neck 35(6):868-876

11. Cooley ME, Siefert ML (2016) Assessment of multiple cooccurring cancer symptoms in the clinical setting. Semin Oncol Nurs 32(4):361-372

12. Haisfield-Wolfe ME, McGuire DB, Soeken K, Geiger-Brown J, de Forge B, Suntharalingam M (2012) Prevalence and correlates of symptoms and uncertainty in illness among head and neck cancer patients receiving definitive radiation with or without chemotherapy. Support Care Cancer 20(8):1885-1893

13. Mashberg A, Boffetta P, Winkelman R, Garfinkel L (1993) Tobacco smoking, alcohol drinking, and cancer of the oral cavity and oropharynx among U.S. veterans. Cancer 72(4):1369-1375

14. Rogers LQ, Malone J, Rao K, Courneya KS, Fogleman A, Tippey A et al (2009) Exercise preferences among patients with head and neck cancer: prevalence and associations with quality of life, symptom severity, depression, and rural residence. Head Neck 31(8):994-1005

15. Pytynia KB, Dahlstrom KR, Sturgis EM (2014) Epidemiology of HPV-associated oropharyngeal cancer. Oral Oncol 50(5):380-386

16. Rogers LQ, Courneya KS, Robbins KT, Malone J, Seiz A, Koch L et al (2006) Physical activity and quality of life in head and neck cancer survivors. Support Care Cancer 14(10):1012-1019

17. Rogers LQ, Courneya KS, Robbins KT, Malone J, Seiz A, Koch L et al (2008) Physical activity correlates and barriers in head and neck cancer patients. Support Care Cancer 16(1):19-27

18. Desai M, Rachet B, Coleman MP, McKee M (2010) Two countries divided by a common language: health systems in the UK and USA. J R Soc Med 103(7):283-287

19. Govers TM, de Kort TB, Merkx MA, Steens SC, Rovers MM, de Bree R et al (2016) An international comparison of the management of the neck in early oral squamous cell carcinoma in the Netherlands, UK, and USA. J Cranio-Maxillo-Fac Surg 44(1):62-69

20. Prochaska JO, Velicer WF (1997) The transtheoretical model of health behavior change. Am J Health Promot 12(1):38-46

21. Liverpool City Council (2015) The index of multiple deprivation 2015: a Liverpool analysis. Liverpool City Council, Liverpool

22. Spector D, Battaglini C, Groff D (2013) Perceived exercise barriers and facilitators among ethnically diverse breast cancer survivors. Oncol Nurs Forum 40(5):472-480

23. Godin G, Shephard RJ (1985) A simple method to assess exercise behavior in the community. Can J Appl Sport Sci 10(3):141-146 
24. Rogers SN, Gwanne S, Lowe D, Humphris G, Yueh B, Weymuller EA Jr (2002) The addition of mood and anxiety domains to the University of Washington quality of life scale. Head Neck 24(6):521-529

25. Rogers SN, Lowe D, Yueh B, Weymuller EA Jr (2010) The physical function and social-emotional function subscales of the University of Washington Quality of Life Questionnaire. Arch Otolaryngol Head Neck Surg 136(4):352-357

26. British Heart Foundation (2016) The national audit of cardiac rehabilitation: annual statistical report. http://www.cardiacrehabilitation.org.uk/docs/BHF_NACR_Report_2016.pdf. Accessed 3 March 2017

27. Halas J, Gannon G (2006) Principles of physical fitness development: implication for fitness assessment. Phys Health Educ J 71(4):4-9

28. Buckingham SA, Taylor RS, Jolly K, Zawada A, Dean SG, Cowie A et al (2016) Home-based versus centre-based cardiac rehabilitation: abridged Cochrane systematic review and meta-analysis. Open Heart 3(2):e000463

29. Galliano-Castillo N, Cantarero-Villanueva I, Fernández-Lao C, Ariza-Garcıa A, Díaz-Rodríguez L, Del-Moral-Ávila R et al
(2016) Telehealth system: a randomized controlled trial evaluating the impact of an internet-based exercise intervention on quality of life, pain, muscle strength, and fatigue in breast cancer survivors. Cancer 122(20):3166-3174

30. Stutts WC (2002) Physical activity determinants in adults: perceived benefits, barriers, and self-efficacy. AAOHN J 50(11):499-507

31. Samuel SR, Maiya A, Babu AS, Vidyasagar MS (2013) Effect of exercise training on functional capacity and quality of life in head and neck cancer patients receiving chemoradiotherapy. Indian $\mathbf{J}$ Med Res 137(3):515-520

32. Davies A, Bagg J, Laverty D, Sweeney P, Filbet M, Newbold $\mathrm{K}$ et al (2010) Salivary gland dysfunction ('dry mouth') in patients with cancer: a consensus statement. Eur J Cancer Care 19(2):172-177

33. Koskela HO (2007) Cold air-provoked respiratory symptoms: the mechanisms and management. Int J Circumpolar Health 66(2):91-100

34. Silver JK (2015) Cancer prehabilitation and its role in improving health outcomes and reducing health care costs. Semin Oncol Nurs 31(1):13-30 